\title{
Learning in Sub-Saharan Africa
}

\author{
Johannes Hoogeveen and Mariacristina Rossi
}

\begin{abstract}
This introductory chapter provides an overview of this book, which investigates educational outcomes in Sub-Saharan Africa with reference to one specific country: Togo.
\end{abstract}

Keywords Africa $\cdot$ Togo $\cdot$ Education $\cdot$ School enrollment $\cdot$ Learning outcomes

\subsection{InTRODUCTION}

Across Africa, the vision that education can be a powerful device to transform lives is widely shared. Unsurprisingly, most parents in the region will say that their priority is assuring a good education for their children. This is reflected in the results from the latest round of the World Values Survey (2010-2014): almost 80\% of African parents responded to be worried or very worried about their ability to give their children a good education.

J. Hoogeveen $(\square)$

World Bank, Washington, DC, USA

e-mail: jhoogeveen@worldbank.org

M. Rossi

School of Management and Economics, Università di Torino, Turin, Italy e-mail: mariacristina.rossi@unito.it

(C) International Bank for Reconstruction and Development/The World Bank 2019

J. Hoogeveen and M. Rossi (eds.), Transforming Education Outcomes in Africa, https://doi.org/10.1007/978-3-030-12708-4_1 
The importance given to education by parents is echoed in the economics literature, which finds that a country's education level is critical for its economic success. For many years, this literature focused on the positive effects of the quantity of education on growth (Barro 1991; Mankiw et al. 1992). Also, in practice much effort goes into assuring that every child has the opportunity to attend school. Driven in large part by the Millennium Development Goal of achieving a 100\% primary completion by 2015 , many countries in Africa put in place policies that abolished school fees and assured free and universal primary education. These efforts have largely been successful, at times extremely successful. In Uganda, for instance, the removal of direct costs to schooling increased primary enrollment by over $60 \%$ and lowered cost-related dropouts by over 33 percentage points (Deininger 2003). The expansion of schooling across the continent is remarkable in its scope and speed. Was in 1970 the gross primary enrollment rate in Sub-Saharan Africa $68 \%$, presently it is over $100 \%$. Average years of schooling of people aged 15 and over increased from 3.89 in 1990 to 5.23 by 2010 . Over the same period, those with no schooling at all dropped from 44 to $32 \%$ (Barro and Lee 2013).

More recently a growing body of evidence suggests it is not only the quantity of schooling, measured by average years of schooling or enrollment rates but also the quality of schooling, proxied by student achievement tests, that contributes to growth. Enrollment, despite being the first step, is not equivalent to education. Enrollment alone is not enough to generate sufficient knowledge capital that economies need to grow. Education needs to equip each child with adequate competencies in literacy, numeracy and science. It is not about being in school but what is learned in school that matters (Hanushek and Kimko 2000; Pritchett 2001; Hanushek and Woessmann 2007, 2012).

Unfortunately, there is often a trade-off between going to school and learning. Particularly when enrollment rates increase rapidly, learning outcomes tend to suffer. In a recent paper, Hoogeveen and Rossi (2013) showed for Tanzania that the impact of the introduction of free primary education school reform had a negative impact on grade achievements. The results also point at an unequal effect, as the negative impact was particularly marked for those living in rural areas and originating from poor families. Perhaps unsurprisingly in view of the rapid expansion of Africa's primary education system, learning outcomes are increasingly of 


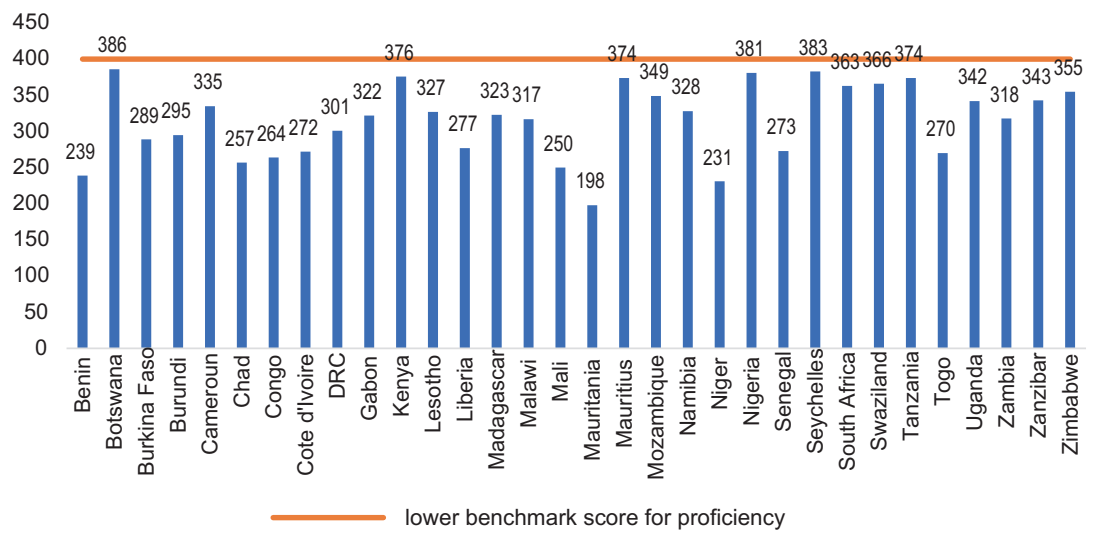

Fig. 1.1 Proficiency in primary education across Africa (Source Authors' calculations using the Altinok et al. data base)

concern (Bashir et al. 2018). Evidence from the global dataset on education quality compiled by Altinok et al. (2017) demonstrates the degree to which African primary school systems perform unsatisfactorily. Across the region, school systems are unable to meet the lower bar for proficiency, set at a score of 400 . The higher benchmark of intermediate proficiency (set at 475) is entirely out of reach, even though it is achieved in Central and Eastern Asia, Europe and North America. Within sub-Saharan Africa there are large differences, however. With an average score of 253, francophone West Africa performs worse than the remainder of the region that has an average score of 331; within francophone West Africa Togo does better than the average with a score of 270 (Figure 2.8 suggests this is driven by Togo's performance on mathematics and not by proficiency in French for which Togo trails countries in the sub-region) $)^{1}$ (Fig. 1.1).

The consequences of such low learning outcomes are severe. According to the Brookings Institution's Center for Universal Education, and drawing data from its Africa Learning Barometer, ${ }^{2} 61$ million children (half of the primary school-age population) "will reach their adolescent years without being able to read, write or perform basic numeracy tasks." Their study identified 12 countries in Africa, namely,

\footnotetext{
${ }^{1}$ The Altinok et al. dataset does not include the data from the latest SACMEQ III round, so for a recent comparison across the subregion, the reader should refer to Fig. 2.8.

${ }^{2}$ http://www.brookings.edu/research/interactives/africa-learning-barometer.
} 
Malawi, Zambia, Ivory Coast, Ghana, Benin, Nigeria, Chad, Ethiopia, Congo, South Africa, Namibia and Comoros in which not even $30 \%$ of children meet the minimum standard of learning by grade five of primary school. But the consequences of poor education go much beyond limited learning. Quality education has been linked to better labor market outcomes and higher levels of income (Hanushek et al. 2017), less poverty (Jung and Thorbecke 2003) and improved health and nutrition. It has also been associated with lower fertility, less inequality, a smaller probability of incarceration and even a higher propensity for happiness (Cuñado and de Gracia 2012).

This book delves deeper into questions of enrollment and learning outcomes. In particular, it asks the question what, given increased enrollment rates, a country can do to bring its learning outcomes up to standard. We explore the scope for improvements, by enhancing the efficiency with which resources are used, by improving the qualifications of teachers but also through greater community involvement in school management. We find that there is certainly scope for improvement. Yet we conclude that changes at the margin will be insufficient to bring about the transformation that is needed to not only achieve intermediate proficiency levels but to go beyond this and attain intermediate proficiency levels. What could be done to transform the education system is discussed in the last chapter.

The focus of this book is on one country, Togo. By picking one country we are able to go into greater depth. Togo was selected because the challenges its education system faces are broadly comparable to those in other education systems in sub-Saharan Africa. The choice of Togo was facilitated by the fact that a broad range of micro data is available, including household surveys, learning surveys as well as detailed administrative data on budgets and the school system. We draw on these data for this book.

The rest of this book is laid out as follows. Chapter 2 gives an overview of the educational system and outcomes in Togo. Chapter 3 uses an efficiency frontier approach and examines the regional differences in educational outcomes in Togo. Chapter 4 illustrates the determinants of children's learning outcomes using survey data by including information on school characteristics and teacher proficiency. Conclusions follow in Chapter 5. 


\section{APPENDIX}

\section{Data Used in This Study}

Several datasets are going to be used in the remainder of this book. In addition to PASEC, which covers learning by pupils in grade two and five of primary school children, we will make use of selected years of the school census containing data for all schools. This administrative data set contains much information on schools itself but lacks information on the demand side, i.e. characteristics of the household from which the students originate. From this dataset a pronounced heterogeneity stands out. The best performing schools are private schools; Kara, Lomé and the Central region are the regions with the highest levels of performance. There is also a clear gender dimension in school performances, which suggests that in all regions and across all school types boys perform better than girls, in contrast to the OECD evidence which shows opposite direction. Results will be shown in Chapter 3. In this chapter we also make use of survey data, QUIBB, to relate school performance to household characteristics and control for wealth indicators. The survey data refer to 2006 and 2011 and contain 7500 interviewed households during the first wave, including 36,430 individuals, whereas 5532 households and 29,781 individuals took part to the second wave. These cross-sectional datasets are extremely useful for the purpose of our research as they provide information on household composition, education, health, employment, assets, current expenditure, autoconsumption and income. Moreover, the dataset contains school attendance in the past week rather than school enrollment as in the administrative data, shedding light on the actual decision on going to school rather than being (merely) enrolled. In Chapter 4, we make use of survey data complementary to PASEC, the SDI data, which focus on pupils in their fourth grade. SDI data contain, in addition to pupils' data, information on teachers' such as their working history as well as their knowledge in math and French.

\section{REFERENCES}

Altinok, Nadir, Noam Angrist, and Harry Patrinos. 2017. A Global Dataset on Education Quality (1965-2015). World Bank Policy Research Working Paper No. 8314. 
Barro, Robert J. 1991. Economic Growth in a Cross Section of Countries. The Quarterly Journal of Economics 106 (2): 407-443.

Barro, Robert J., and Jong Wha Lee. 2013. A New Data Set of Educational Attainment in the World, 1950-2010. Journal of Development Economics 104 (2013): 184-198.

Bashir, Sajitha, Marlaine Lockheed, Elizabeth Ninan, and Jee-Peng Tan. 2018. Facing Forward: Schooling for Learning in Africa. Africa Development Forum Series. Washington, DC: World Bank. https://doi. org/10.1596/978-1-46481260-6.

Cuñado, J., and F.P. de Gracia. 2012. Does Education Affect Happiness? Evidence for Spain. Social Indicators Research 108: 185-196. https://doi. org/10.1007/s11205-011-9874-x.

Deininger, Klaus. 2003. Does Cost of Schooling Affect Enrollment by the Poor? Universal Primary Education in Uganda. Economics of Education Review 22 (3): 29l-305.

Hanushek, E.A., and D.D. Kimko. 2000. Schooling, Labor-Force Quality, and the Growth of Nations. American Economic Review 90 (5): 1184-1208.

Hanushek, E.A., and L. Woessmann. 2007. The Role of Education Quality in Economic Growth. World Bank Policy Research Working Paper, 4122, Washington, DC.

Hanushek, E.A., and L. Woessmann. 2012. Do Better School Lead to More Growth? Cognitive Skills, Economic Outcomes, and Causation. Journal of Economic Growth 17 (4): 267-321.

Hanushek, Eric A., Guido Schwerdt, Ludger Woessmann, and Lei Zhang. 2017. General Education, Vocational Education, and Labor-Market Outcomes Over the Lifecycle. Journal of Human Resources 52 (1): 48-87.

Hoogeveen, Johannes, and Mariacristina Rossi. 2013. Enrollment and Grade Attainment Following the Introduction of Free Primary Education in Tanzania. Journal of African Economies 22 (3): 375-393.

Jung, Hong-Sang, and Erik Thorbecke. 2003. The Impact of Public Education Expenditure on Human Capital, Growth, and Poverty in Tanzania and Zambia: A General Equilibrium Approach. Journal of Policy Modeling 25 (8): $701-725$.

Mankiw, N. Gregory, David Romer, and David N. Weil. 1992. A Contribution to the Empirics of Economic Growth. The Quarterly Journal of Economics 107 (2): 407-437.

Pritchett, Lant. 2001. Where Has All the Education Gone? World Bank Economic Review 15 (3): 367-391. 
The opinions expressed in this chapter are those of the author(s) and do not necessarily reflect the views of the International Bank for Reconstruction and Development/The World Bank, its Board of Directors, or the countries they represent.

Open Access This chapter is licensed under the terms of the Creative Commons Attribution 3.0 IGO License (https://creativecommons.org/ licenses/by/3.0/igo/), which permits use, sharing, adaptation, distribution and reproduction in any medium or format, as long as you give appropriate credit to the International Bank for Reconstruction and Development/The World Bank, provide a link to the Creative Commons license and indicate if changes were made.

The use of the International Bank for Reconstruction and Development/The World Bank's name, and the use of the International Bank for Reconstruction and Development/The World Bank's logo, shall be subject to a separate written license agreement between the International Bank for Reconstruction and Development/The World Bank and the user and is not authorized as part of this CC-IGO license. Note that the link provided above includes additional terms and conditions of the license.

The images or other third party material in this chapter are included in the chapter's Creative Commons license, unless indicated otherwise in a credit line to the material. If material is not included in the chapter's Creative Commons license and your intended use is not permitted by statutory regulation or exceeds the permitted use, you will need to obtain permission directly from the copyright holder.

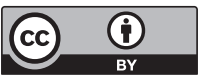

